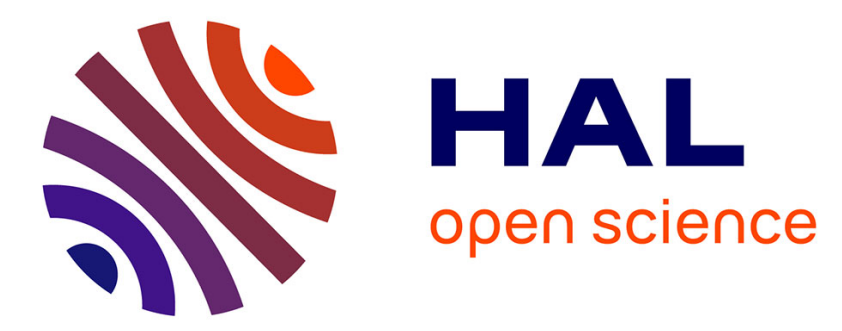

\title{
Structural Study of Interlayer Zr Particles in Exchanged and Pillared Beidellite
}

\author{
J. Miehé-Brendlé, L. Khouchaf, J. Baron, M.-H. Tuilier
}

\section{To cite this version:}

J. Miehé-Brendlé, L. Khouchaf, J. Baron, M.-H. Tuilier. Structural Study of Interlayer Zr Particles in Exchanged and Pillared Beidellite. Journal de Physique IV Proceedings, 1997, 7 (C2), pp.C2-951-

C2-952. 10.1051/.jp4:1997297 . jpa-00255371

\section{HAL Id: jpa-00255371 https://hal.science/jpa-00255371}

Submitted on 1 Jan 1997

HAL is a multi-disciplinary open access archive for the deposit and dissemination of scientific research documents, whether they are published or not. The documents may come from teaching and research institutions in France or abroad, or from public or private research centers.
L'archive ouverte pluridisciplinaire HAL, est destinée au dépôt et à la diffusion de documents scientifiques de niveau recherche, publiés ou non, émanant des établissements d'enseignement et de recherche français ou étrangers, des laboratoires publics ou privés. 


\title{
Structural Study of Interlayer Zr Particles in Exchanged and Pillared Beidellite
}

\author{
J. Miehé-Brendlé, L. Khouchaf*, J. Baron and M.-H. Tuilier*
}

Laboratoire de Matériaux Minéraux, E.N.S.C.M.U., Université de Haute Alsace, 3 rue A. Werner, 68093 Mulhouse, France

* Laboratoire de Physique et de Spectroscopie Électronique, F.S.T., Université de Haute Alsace, 4 rue des frères Lumière, 68093 Mulhouse, France

\begin{abstract}
Zirconia pillared clays (with synthetic beidellite as host material) were prepared by replacing the sodium interlayer cations by zirconium hydroxy polycations, and then heating to stabilize the structure. The pillaring solution was an aqueous solution of zirconyl chloride, but the structure of the polycation which is intercalated remains unknown. From the XRD data, the interlayer spacing was found to be $9 \AA$ in $Z$ r exchanged beidellite and slightly lower $(7 \AA)$ after calcination. The local environment of zirconium in solid zirconyl chloride and in the pillaring solution was first examined and then in the ionexchanged and calcined beidellite. The EXAFS results for zirconyl chloride in the solid state and in aqueous solution, showed that the nearest neighbours and the next-nearest-neighbours environments of $\mathrm{Zr}$ are identical in solid and in solution. In the $\mathrm{Zr}$ exchanged beidellite, the $\mathrm{Zr}_{r}$ cations have the same environment as in the pillaring solution. On the opposite, the mean $\mathrm{Zr}-\mathrm{O}$ and $\mathrm{Zr}$-Zr distances in the calcined sample are shortened with respect to $Z_{r}$-exchanged beidellite.
\end{abstract}

The main interest in clays pillaring is to generate tailor-made structures by controlling the size and population of pillars between the silicate layers. These materials have therefore potential as catalysts in hydrocarbon hydrocracking and for a wide variety of proton catalysed reactions. Among all the pillaring species, $\mathrm{Zr}$ is one of the few transition metals known to provide stable pillars. Zirconyl chloride solutions are usually used in the ion exchange step [1] but despite all the work already carried out in this field, the structure of the hydroxy-Zr compounds in the intercalated clay is not clearly established and the transformation into $\mathrm{ZrO}_{2}$ has not really been evidenced.

Zirconyl chloride octahydrate $\mathrm{ZrOCl}_{2}, 8 \mathrm{H}_{2} \mathrm{O}$ used to prepare the pillaring solution crystallizes in the tetragonal symmetry $(a=17.08 \AA$ and $c=7.69 \AA$ )[2]. In the zirconyl unit, four Zr atoms are located at the corners of a sligthly distorted square and linked along each edge of the square by two OH groups, one above and one below the plane of the square. Four water molecules are bonded to each zirconium atom and the arrangement of the eight oxygens around $\mathrm{Zr}$ is a distorted square antiprism. The $\mathrm{Zr}-\mathrm{O}$ distances distribution scatters over $0.28 \AA$ and rises at three values, i.e., 2.09-2.13 $\AA, 2.22-2.23 \AA$ and 2.35-2.37 $\AA$ respectively with an average value of $2.24 \AA$.

The $0.06 \mathrm{M}$ aqueous solution used to perform the ion exchange was prepared from zirconyl chloride $\left(\mathrm{ZrOCl}_{2}, 8 \mathrm{H}_{2} \mathrm{O}, 98 \%\right.$ Fluka). The $\mathrm{Zr}$-exchanged and pillared beidellite were obtained by replacing the interlayer $\mathrm{Na}^{+}$cations of a synthetic beidellite by zirconium hydroxy polycations and calcining at $500^{\circ} \mathrm{C}[3]$.

The X-ray absorption experiments were performed at LURE (DCI) on the XAS2 beam line equipped with a Si(311) twocrystal spectrometer. The data were recorded at the $\mathrm{Zr}-\mathrm{K}$ edge, in the transmission mode, from $\mathrm{ZrOCl}_{2}, 8 \mathrm{H}_{2} \mathrm{O}$ (crystal) at roOm temperature (RT) and $16 \mathrm{~K}, \mathrm{ZrOCl}_{2}$ aqueous solution at $\mathrm{RT}$ and $\mathrm{Zr}$-exchanged $(\mathrm{ZrEB})$ and pillared beidellite (PB) at $\mathrm{RT}$ and $16 \mathrm{~K}$.

The normalized $k \chi(k)$ spectra [4] are shown in Fig. 1. The Fourier transforms (FT) between 3 and $15 A^{-1}$ of $k^{3}$ weighted $\chi(k)$ data recorded from liquid and solid $\mathrm{ZrOCl}_{2}$ are compared in Fig.2. Fits of Fourier filtered contributions of oxygen nearest neighbours (NN) and zirconium next-nearest-neighbours (NNN) of Zr were performed in k-space from 3 to $1 \AA^{-1}$ using theoretical phase shifts and backscattering (BS) amplitudes generated by FEFF6 [5]. The results are presented in Table 1.

Table 1 : Structural parameters deduced from EXAFS

\begin{tabular}{ccccccc}
\hline Samples & $\mathrm{Zr}-\mathrm{O}(\AA)$ & $\mathrm{N}_{1}$ & $\sigma_{1}(\AA)$ & $\mathrm{Zr}-\mathrm{Zr}(\AA)$ & $\mathrm{N}_{2}$ & $\sigma_{2}(\AA)$ \\
\hline $\mathrm{ZrOCl}_{2}$ (crystal) & $2.22 \pm 0.02$ & $8 \pm 1$ & 0.10 & $3.57 \pm 0.02$ & $1.9 \pm 0.5$ & 0.03 \\
$\mathrm{ZrOCl}_{2}$ (solution) & $2.22 \pm 0.01$ & $7.9 \pm 0.8$ & 0.10 & $3.58 \pm 0.04$ & $1.2 \pm 0.8$ & 0.07 \\
$\mathrm{ZrEB}$ & $2.21 \pm 0.01$ & $8 \pm 0.3$ & 0.10 & $3.59 \pm 0.02$ & $1.3 \pm 0.3$ & 0.07 \\
$\mathrm{~PB}$ & $2.16 \pm 0.02$ & $6.1 \pm 1.4$ & 0.11 & $3.38 \pm 0.02$ & $1.9 \pm 0.6$ & 0.11 \\
\hline
\end{tabular}




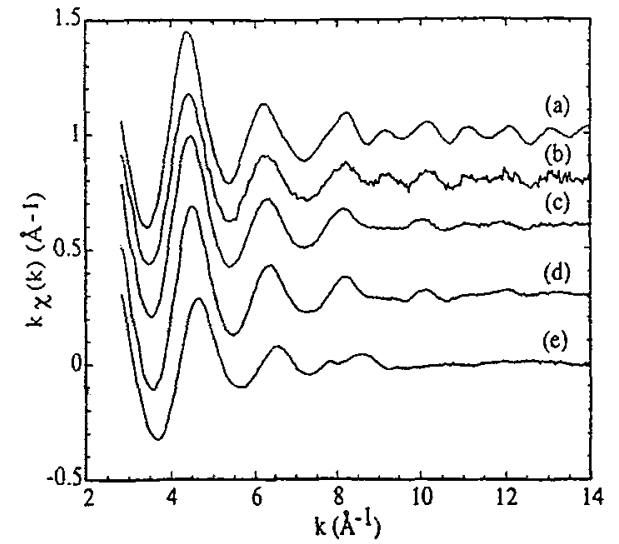

Fig.1 : Normalized $\mathrm{k} \chi(\mathrm{k}$ ) spectra from $\mathrm{ZrOCl}$ crystal at (a) $16 \mathrm{~K}$, (b) RT, (c) aqueous solution at RT, (d) ZrEB at $16 \mathrm{~K}$ (e) PB at $16 \mathrm{~K}$.

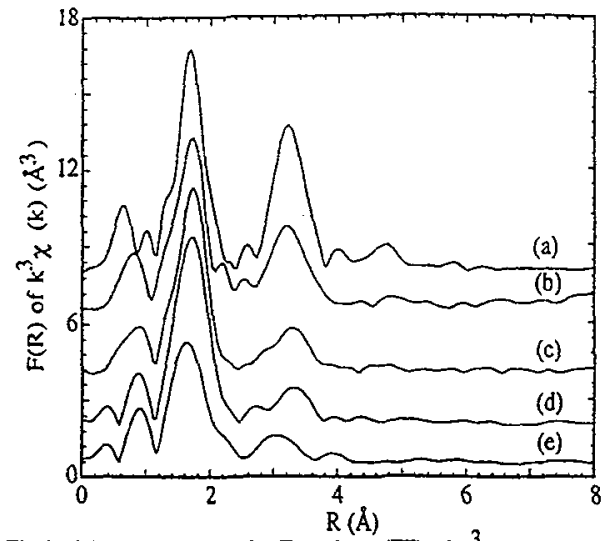

Fig. 2 : Magnitude of Fourier Transform (FT) of $\mathrm{k}^{3} \chi(\mathrm{k})$ from $\mathrm{ZrOCl}_{2}$ crystal at (a) $16 \mathrm{~K}$, (b) RT, (c) aqueous solution at RT, (d) ZrEB at $16 \mathrm{~K}$, (e) $\mathrm{PB}$ at $16 \mathrm{~K}$.

The shape and position of the next neighbour (NN) peak are quite similar for both samples. The value of $2.22 \pm 0.02 \AA$ deduced from EXAFS is close to the center of the bond lengths distribution, i.e., $2.24 \mathrm{~A}$. The apparent shortening of the mean coordination radius comes from the weil-known effect of asymmetric pair distribution $\left(\sigma^{2}>0.01 \AA^{2}\right)$ which reduces slightly the weight of the longest distances with respect to the shortest ones. Neverthless, $\sigma^{2}$ is considered to be small enough to use the phase shifts and BS amplitudes extracted from the analysis of the $\mathrm{ZrOCl}_{2}$ spectrum at $16 \mathrm{~K}$ in the simulations of the NN contribution in beidellite samples. The peak located at about 3.2 $\AA$ in the FT (Fig. 2) corresponds to Zr NNN of Zr. Its amplitude is more and more lowered at $\mathrm{RT}$ and in the solution. In $\mathrm{ZrOCl}{ }_{2}$ (crystal) each $\mathrm{Zr}$ cation has two $\mathrm{ZrNNN}$ at $3.57 \AA$. This value deduced from simulations is in fair agreement with crystallographic data [2]. Again no major difference between solid and solution is found excepted a small increase of $\sigma$ in the latter, which indicates a loss of local order. Therefore this preliminary study shows that NN and NNN environments around $\mathrm{Zr}$ are identical in the solid and in solution. There is no structural difference between the zirconyl ion present in the solution and in solid $\mathrm{ZrOCl}_{2}, 8 \mathrm{H}_{2} \mathrm{O}$, in agreement with the hypothesis of Fryer et al. [6] on the basis of an electron microscopic study.

Moreover, the FT of $k^{3}$ weighted $\chi(k)$ data recorded from $\mathrm{Zr}$-exchanged beidellite ( $\mathrm{ZrEB}$ ) (Fig. 2.d.) reveals that the NN distribution is the same as that recorded from the pillaring solution [3]. The values of $R, N$ and $\sigma$ extracled from the simulations (Table 1) are identical in both to within the uncertainty of the EXAFS method. This result is in agreement with the hypothesis of insertion of the polycation between the silicate layers of the clay. On the opposite, the FT of calcined beidellite (PB) exhibits a clearly visible shift of the NN and NNN peaks towards smaller coordination numbers with respect to the Zrexchanged one (Fig 2.e.). The results of the simulation of the filtered NN distribution gives 6 oxygen anions at $2.16 \AA$ in the calcined sample instead of 8 at $2.21 \AA$ in the exchanged one (Table 1). The value of $2.16 \AA$ in calcined beidellite is close to the mean $\mathrm{Zr}$-O distance in monoclinic $\mathrm{ZrO}_{2}[7,8]$ although the coordination number is slightly lower. The distance of $\mathrm{Zr}$ to the $\mathrm{Zr}$ NNN is also found to be shorter than in $\mathrm{ZrO}_{2}[8]$ and the coordination number $\mathrm{N}_{2}$ remains the same as in the zirconyl ion. More details will be found in ref [3]. These results, which demonstrate the change in the structure of $\mathrm{Zr}$ oxide clusters located inside the pillared beidellite can be related to the interlayer spacing decrease from 9 to $7 \AA$ observed by XRD before and after calcination respectively in agreement with the results obtained by Ohtsuka et al [9]. This interlayer spacing of $7 \AA$ corresponds to about twice the $\mathrm{Zr}$ NNN distance. Nevertheless, the size of the cluster becomes too small to reach that of the $\mathrm{ZrO}_{2}$ unit cell.

In conclusion, the hydrolysis of the zirconyl ion does not infer major changes in the $\mathrm{Zr}$ environment. The decrease of the interlayer spacing after calcination of the $\mathrm{Zr}$-exchanged beidellite is related to the change of structure of the $\mathrm{ZrO}$ cluster located between the aluminosilicate layers. This study gives thus an additional proof of the transformation of the intercalated polycations into metal oxide particles.

\section{References}

[1] Yamanaka S. and Brindley G.W. Clays and Clay Minerals 27 (1979) 119 -124 .

[2] Clearfield A. and Vaughan P. Acta Cryst. 9 (1956) 555-558.

[3] Miehé-Brendle J., Khouchaf L., Baron J. and Tuilier M.-H., to be published.

[4] Michalovicz A., Logiciel pour la chimie (Société Française de Chimie, Paris, 1991) pp. 102-103.

[5]Mustre de Leon J., Rehr J.J., Zabynsky S.I. and Albers R.C., Phys. Rev. B 44 (1991) 4146- 4156.

[6] Fryer F. R., Hutchinson J. L.and Paterson R., J. Colloid Interface Sci. 34 (1970) 238-248.

[7] Tuilier M.-H., Dexpert-Ghys J., Dexpert H. and Lagarde P., J. Solid State Chem. 69 (1987)153-161 .

[8] Li P., Chen I.- W. and Penner Hahn J. E., Phys. Rev. B 48 (1993) 10063-10073.

[9] Ohtsuka K. , Hayashi Y.and Suda M., Chem. Mater. 5 (1993) 1823-1829. 